\title{
Analisis Laba Kotor Sebagai Alat Untuk Menentukan Naik Turunnya Harga Jual Pada Qmart Superstore Kota Gorontalo
}

\author{
Muhammad Ardi \\ IAIN Sultan Amai Gorontalo \\ Muhammadardi1601@gmail.com
}

\begin{abstract}
The problem happen in many companies is companies which often underestimate gross profit they obtain, so the company only focuses in net profit. But if it sees deeper, gross profit is able to describe the management itself, especially to determine the rise and fall of the sale price. The aim of this research is to investigating the gross profit in determine the rise and fall of the sale price in Qmart Superstore Gorontalo. The research method is taking 10 indofood products as sample of whole products.

The price sale and main price Sun BC Beras Merah 8x20 Gr, Indomilk Full Cream 800 Gr, La Fonte Sphagetti 500 Gr, Chitato Beef Barbeque 68 Gr, Promina Biscuit Susu 130 Gr, Qtela Original 185 Gr, Happy Salad Pure Soya Oil 5 Ltr, Bu Krim Oxy Clean Higienis $750 \mathrm{Gr}$ and Indomilk Instant $400 \mathrm{Gr}$ is increase from 2014 to 2017 . Wherease products Bimoli classic 5 Ltr is decrease in 2016 and increase in 2014, 2015, and 2017.

The quantity of sale and main price of Sun BC Beras Merah 8x20 Gr, Indomilk Full Cream 800 Gr, La Fonte Sphagetti 500 Gr, Chitato Beef Barbeque 68 Gr, Promina Biscuit Susu 130 Gr, Qtela Original 185 Gr, Happy Salad Pure Soya Oil 5 Ltr, Bu Krim Oxy Clean Higienis $750 \mathrm{Gr}$ and Indomilk Instant $400 \mathrm{Gr}$ is changing in flexibility from 2014-2017. The change of sale quantity is cause by the consumer and the price sale itself.
\end{abstract}

\section{Keywords: Gross Profit Analysis, Price Sale.}

\section{A. Pendahuluan}

Organisasi didirikan dengan memiliki maksud dan tujuan tertentu. Ada yang bertujuan hanya untuk membantu masyarakat tanpa mengharapkan laba. Organisasi tersebut sering dijuluki sebagai organisasi nirlaba, atau perusahaan nirlaba. Berbeda dengan perusahaan jasa, dagang dan manufaktur yang lebih fokus dalam mencari keuntungan dengan cara memasarkan produk/barang atau jasa mereka.

Setiap perusahaan atau badan usaha yang berorientasi pada laba harus membuat laporan keuangan. Laporan keuangan adalah gambaran keseluruhan perusahaan yang bersifat financial dan dibuat selama periode tertentu. Laporan keuangan terdiri dari laporan Neraca, Laporan Laba Rugi, Laporan Perubahan Ekuitas, Laporan Arus kas, dan Catatan Atas Laporan Keuangan.

Laporan keuangan yang tersaji bukan hanya sebatas pajangan saja, melainkan harus dilakukan evaluasi lebih lanjut agar dapat diketahui kesehatannya. Dalam mengevaluasi kinerja keungannya, perusahaan lebih fokus pada laporan neraca dan laporan laba ruginya. Karena didalam neraca tertuang jumlah harta, hutang dan modal perusahaan yang menjadi dasar jalannya aktivitas perusahaan. Sedangkan laporan laba rugi memuat pendapatan, beban dan laba yang dihasilkan oleh perusahaan. 
Evaluasi yang dilakukan oleh perusahaan harus diawali dengan cara menganalisa setiap data pada laporan keuangan dengan membandingkan pos per pos atau periode sa ${ }^{\mathrm{t}}$ tu dengan periode lainnya. Evaluasi ini menggunakan analisis laporan keuangan. Analisis laporan keuangan ada banyak metode yang semuanya memiliki tujuan masing-masing. Seperti analisis profitabilitas yang memiliki tujuan untuk mengetahui kemampuan perusahaan dalam menghasilkan laba.

Laba merupakan sesuatu yang sangat penting untuk kelangsungan hidup perusahaan, dimana angka laba yang tertera mampu merepresentasikan kinerja perusahaan secara keseluruhan. Menurut Kasmir (2016:305) Laba yang diperoleh perusahaan terdiri dari dua macam :

1. Laba Kotor (Gross Profit), laba yang didapatkan sebelum dikurangi dari biayabiaya yang menjadi beban perusahaan tersebut.

2. Laba Bersih (Net Profit), laba yang telah dikurangi biaya-biaya yang merupakan beban peusahaan dalam suatu periode tertentu, termasuk pajak.

Kebanyakan perusahaan menyepelekan laba kotor yang mereka peroleh, sehingga mereka hanya fokus pada keuntungan bersihnya saja. Memang, laba kotor yang diperoleh hanyalah keuntungan yang belum sepenuhnya dapat dinikmati, karena keuntungan tersebut masih harus dikurangi dengan biaya-biaya lainnya. Namun, jika dilihat secara lebih dalam, laba kotor ternyata mampu menggambarkan kinerja manajemen perusahaan itu sendiri. Pada dasarnya perolehan Laba Kotor pada perusahaan sangatlah dipengaruhi oleh aktivitas penjualan, baik itu penjualan barang maupun penjualan jasa. Hal ini dapat dilihat dari laba kotor yang diperoleh dari periode ke periode selalu berbeda-beda, karena volume barang yang dijual dan harga jual yang tidak tetap. Seperti yang diketahui, laba kotor adalah hasil yang diperoleh dari selisih antara penjualan dan harga pokok penjualan, yang merupakan penggambaran dari upaya dalam memenuhi rencana dan anggaran keuntungan yang ingin perusahaan peroleh. Pada perusahaan dagang laba kotor memuat hasil kinerja bagian operasional, bagian penjualan dan pihak manajemen.

Bagian operasional bertanggung jawab dalam mengadakan sebuah produk atau barang yang akan dijual sesuai dengan target yang telah ditentukan. Setelah persediaan barang dagang telah memenuhi kuota, maka tanggung jawab tersebut diserahkan ke bagian penjualan guna dipasarkan secara langsung ataupun melalui penyaluranpenyaluran yang ada dengan harga yang sesuai mutu dan kualitas barang itu sendiri. Sementara pihak manajemen memegang peran penting dari awal hingga akhir, yakni salah satunya menetapkan harga jual. Layaknya harga sebuah produk yang sama, dengan harga yang berbeda disetiap Toko atau tempat penjualan.

Hal yang paling penting bagi aktivitas penjualan tentunya menentukan harga jual. Sebab, harga jual merupakan akar dari laba yang diperoleh. Besarnya harga jual yang ditentukan tentunya dapat menarik keuntungan yang lebih besar dari sebelumnya. Namun, bisa saja justru merugikan perusahaan. Hal ini tentunya membuat pihak manajemen kewalahan dalam menentukan harga jual yang sesuai dengan kondisi pasar. Sebelum dianggarkannya harga jual, maka pihak manajamen harus lebih dulu mengetahui arus naik turunnya harga jual yang berlangsung selama beberapa periode. Hal ini berguna untuk mengetahui penyebab naik turunnya harga jual dan bisa dengan mudah merencanakan harga barang atau produk yang ingin di jual. Analisis laba kotor adalah salah satu cara dalam mengetahui dan menentukan naik turunnya harga jual. Analisis laba kotor merupakan alat yang tepat untuk menentukan naik turunnya harga jual pada perusahaan dagang. Banyak metode penentuan harga jual, akan tetapi metode tersebut lebih menunjang ke arah perusahaan manufaktur. Bedasarkan fenomena saat ini, perusahaan dagang atau biasa disebut dengan pertokoan sering menggunakan metode 
taksiran yang memiliki tingkat keakuratan rendah ataupun metode berbasis pasar, yang hanya melihat dari harga pasaran saat itu.

QMart Superstore merupakan salah satu toko yang ada di Kota Gorontalo, yang menjual berbagai macam produk yakni barang harian, pakaian, dan lain-lain. Toko ini sering ramai dikunjungi oleh banyak kalangan, mulai dari anak kecil hingga dewasa. Maka, penulis tertarik untuk melakukan penelitian di toko ini, mengenai penentuan harga jual dari beberapa sampel yang di ambil dengan melihat laporan laba rugi QMart Superstore selama periode 5 tahun.

\section{B. Tinjauan Teori dan Konsep}

\section{Akuntansi Keuangan}

Zaki Baridwan (2013:1) menjelaskan bahwa akuntansi keuangan disusun terutama untuk menghasilkan informasi, biasanya dalam bentuk laporan keuangan, yang ditujukan pada pihak-pihak di luar perusahaan.

Menurut Sugiarto (2002) Akuntansi Keuangan adalah bidang dalam akuntansi yang berfokus pada penyiapan laporan keuangan suatu perusahaan yang dilakukan secara berkala. Laporan ini sekaligus sebagai bentuk pertanggungjawaban manajemen kepada pemegang saham.

Menurut Warren Reeve Fess (2008:15), "Financial accounting is primarily concerned with the recording and reporting of economic data and activites for a business. Although suchreports provide useful information for managers, they are the primary reports for owners, creditors, governmental agencies, and the public (2008:1)" yang artinya "Akuntansi keuangan adalah pencatatan dan pelaporan data serta kegiatan ekonomi perusahaan. Walaupun laporan tersebut menghasilkan informasi yang berguna bagi manajer, namun hal itu merupakan laporan utama bagi pemilik."

Menurut Martani (2012:8), akuntansi keuangan berorientasi pada pelaporan pihak eksternal. Beragamnya pihak eksternal dengan tujuan spesifik bagi masingmasing pihak membuat pihak penyusun laporan keuangan menggunakan prinsip dan asumsi-asumsi dalam penyusunan laporan keuangan. Untuk itu diperlukan standar akuntansi yang dijadikan pedoman baik oleh penyusun maupun oleh pembaca laporan keuangan. Laporan yang dihasilkan dari akuntansi keuangan berupa laporan keuangan untuk tujuan umum.

Yudiati dan Wahyuni (2006:10) dalam Marina Tjani Ontalu (2015:7) mendefinisikan Akuntansi Keuangan (Financial Accounting) merupakan bidang akuntansi yang berkaitan dengan bagaimana pencatatan dan penyusunan laporan keuangan dari kesatuan unit usaha yang berpedoman pada prinsip-prinsip akuntansi diterima umum.

Surya (2012:1) dalam Indriani Masaluni (2016:6) menjelaskan bahwa akuntansi keuangan adalah proses yang berakhir pada penyiapan laporan keuangan suatu perusahaan secara umum untuk digunakan oleh pihak internal dan eksternal. Akuntansi keuangan menghasilkan laporan keuangan yang menyajikan informasi yang bersifat umum sehingga tidak sepenuhnya dapat memenuhi kebutuhan informasi si pemakai.

Iman Santoso (2010:6) mengemukakan 3 karakteristik penting dalam akuntansi keuangan yaitu Pengidentifikasian, Pengukuran dan Pengomunikasian.

Setelah melihat penjelasan dari beberapa para ahli, maka penulis menyimpulkan bahwa Akuntansi Keuangan adalah salah satu bidang akuntansi yang 
mendalami laporan keungan, mulai dari pencatatan hingga pelaporan hasil kinerja perusahaan yang dilakukan secara berkala dan sesuai dengan aturan SAK serta dapat bermanfaat bagi pihak internal maupun eksternal perusahaan.

\section{Laporan Laba Rugi}

Menurut Hery (2017:114), Laporan laba rugi (income statement) adalah laporan yang menyajikan ukuran keberhasilan operasi perusahaan selama periode waktu tertentu.

Laporan laba rugi terutama menyajikan informasi kinerja. Informasi kinerja diperlukan untuk menilai pertambahan sumber potensial sumber daya ekonomi yang mungkin dikendalikan di masa depan. Informasi kinerja bermanfaat untuk memprediksi kapasitas perusahaan dalam menghasilkan arus kas dari sumber daya yang ada.

Menurut Kasmir (2016:29) laporan laba rugi merupakan laporan keuangan yang menggambarkan hasil usaha perusahaan dalam suatu periode tertentu.

Slamet dan Bogat (2014:42) menjelaskan bahwa laporan laba rugi merupakan titik pangkal penaksiran keberhasilan perusahaan pada periode berikutnya. Masingmasing pos penghasilan dan beban dianalisis secara simultan bersama-sama penghasilan dan beban pada periode-periode yang telah lalu. Dari situ dapat disusun kecenderungan penghasilan dan beban pada periode berikutnya. Sudah tentu metode ini memiliki kemungkinan bias, namun paling tidak merupakan media pengurang ketidakpastian. Tanpa menganalisis hasil operasi perusahaan, orang tidak mampu meramalkan apa yang akan terjadi.

Unsur-unsur utama laporan laba rugi, adalah sebagai berikut :

a. Pendapatan, adalah arus kas masuk aktiva atau peningkatan lainnya atas aktiva atau penyelesaian kewajiban entitas (atau kombinasi dari keduanya) dari pengiriman barang, pemberian jasa, atau aktivitas lainnya yang merupakan operasi utama atau operasi sentral perusahaan.

b. Beban, adalah arus keluar aktiva atau penggunaan lainnya atas aktiva atau terjadinya (munculnya) kewajiban entitas (atau kombinasi dari keduanya) yang disebabkan oleh pengiriman atau pembuatan barang, pemberian jasa, atau aktivitas lainnya yang merupakan operasi utama atau operasi sentral perusahaan.

c. Keuntungan, adalah kenaikan dalam ekuitas (aktiva bersih) entitas yang ditimbulkan oleh transaksi peripheral (transaksi di luar operasi utama atau operasi sentral perusahaan) atau transaksi insidentil (transaksi yang keterjadiannya jarang) dan dari seluruh transaksi lainnya serta peristiwa maupun keadaan-keadaan lainnya yang mempengaruhi entitas, tidak termasuk yang berasal dari pendapatan atau investasi pemilik.

d. Kerugian, adalah penurunan dalam ekuitas (aktiva bersih) entitas yang ditimbulkan oleh transaksi peripheral (transaksi di luar operasi utama atau operasi sentral perusahaan) atau transaksi insidentil (transaksi yang keterjadiannya jarang) dan dari seluruh transaksi lainnya serta peristiwa maupun keadaan-keadaan lainnya yang mempengaruhi entitas, tidak termasuk yang berasal dari beban atau distribusi kepada pemilik.

Menurut Slamet dan Bogat (2014:42) manfaat laporan laba rugi adalah :

1. Laporan laba merupakan tolak ukur keberhasilan perusahaan. Dengan menganalisis laporan laba rugi, para pengguna dapat menilai kemampuan perusahaan dalam mengelola sumber-sumber ekonomik perusahaan agar berhasil guna dan berdaya guna. 
2. Laporan laba rugi merupakan titik pangkal penaksiran keberhasilan perusahaan pada periode berikutnya.

3. Laporan laba rugi merupakan media untuk menilai tingkat kemampuan perusahaan dalam menghasilkan laba.

\section{Analisis Laporan Keuangan}

Analisis laporan keuangan adalah penelaahan aatau mempelajari hubunganhubungan dan tendensi atau kecenderungan untuk mengukur posisi keuangan dari hasilhasil usaha serta perkembangan perusahaan yang bersangkutan. Banyak kelompok yang berkepentingan dengan analisis laporan keuangan, antara lain: pemegang saham, manajemen perusahaan, kreditor dan investor, pemerintah, pemegang saham dan kreditor potensial, bursa saham, asosiasi-asosiasi, karyawan dan serikat pekerja, masyarakat umum lainnya. Dengan demikian maka jelaslah bahwa mengadakan interpretasi atas hasil analisis laporan keuangan suatu perusahaan adalah sangat penting artinya bagi pihak-pihak yang berkepentingan meskipun kepentingan mereka satu sama lainnya berbeda-beda (Iman Santoso, 2009:480).

Dalam melakukan analisis laporan keuangan suatu perusahaan, ada beberapa macam metode analisis yang digunakan. Tujuan dari setiap metode analisis adalah untuk menyederhanakan data keuangan sehingga dapat lebih dimengerti. Untuk itu, sebelum menganalisis serta menginterpretasikan sehingga data itu menjadi lebih berarti. Ada dua metode analisis yang digunakan dalam analisis laporan keuangan, yaitu:

1. Analisis Horizontal (Analisis Dinamis)

Analisis ini digunakan dengan cara membandingakan laporan keuangan untuk beberapa periode, sehingga akan diketahui perkembangannya. Analisis ini disebut juga sebagai analisis trend.

2. Analisis Vertikal (Analisis Statis)

Analisis ini dilakukan dengan cara membandingkan antara pos yang satu dengan pos yang lainnya dalamm laporan keuangan tersebut pada suatu periode tertentu. Dari hasil analisis ini, hanya akan diketahui kesimpulan mengenai keadaan keuangan dan hasil operasi pada saat itu saja tanpa mengetahui perkembangannya.

Kasmir (2016:99) mengatakan bahwa jenis-jenis teknik analisis laporan keuangan yang dapat dilakukan adalah :

a. Analisis perbandingan antara laporan keuangan

b. Analisis trend

c. Analisis persentase per komponen

d. Analisis sumber dan penggunaan dana

e. Analisis sumber dan penggunaan kas

f. Analisis rasio

g. Analisis kredit

h. Analisis laba kotor

i. Analisis titik pulang pokok

\section{Analasis Laba Kotor}

Kusnadi (2001:365) dalam Munirah, dkk, (2014:8) mengatakan bahwa "analisis laba kotor merupakan proses analisis yang berkelanjutan dan harus dilaksanakan secara intensif'. Secara umum pengertian analisis laba kotor adalah analisis yang digunakan untuk mengetahui jumlah laba kotor dari periode satu ke periode lainnya, serta sebabsebab berubahnya laba kotor tersebut antara dua atau lebih periode. 
Adapun pengertian dari analisis laba kotor menurut Supriyono (2000:179) dalam Medi Tri Purwanto (2013:21) adalah memecah-mecah atau membagi menjadi bagianbagian atau elemen-elemen yang lebih kecil dengan tujuan untuk menentukan penyebab penyimpangan laba kotor dan untuk mengetahui hubungan antara elemen-elemen tersebut.

Dari uraian diatas, maka dapat disimpulkan bahwa bahwa analisis laba kotor digunakan untuk mengetahui penyebab perubahan-perubahan atau penyimpanganpenyimpangan yang terjadi antara anggaran laba kotor dan realisasinya. Selanjutnya dengan diketahui penyebabnya, dapat digunakan untuk memutuskan kebijakan ke depan yang berkaitan dengan laba tersebut.

Secara umum manfaat yang dapat diperoleh dari analisis laba kotor adalah :

1. Untuk mengetahui penyebab turunnya harga jual

2. Untuk mengetahui penyebab naiknya harga jual

3. Untuk mengetahui penyebab turunnya harga pokok penjualan

4. Untuk mengetahui penyebab naiknya harga pokok penjualan

5. Sebagai bentuk pertanggungjawaban bagian penjualan akibat naik turunnya harga jual

6. Sebagai bentuk pertanggungjawaban bagian produksi akibat naik turunnya harga pokok

7. Sebagai salah satu alat ukur untuk menilai kinerja manajemen dalam suatu periode

8. Sebagai bahan untuk menentukan kebijakan manajemen ke depan dengan mencermati kegagalan atau kesuksesan pencapai laba kotor sebelumnya

9. Dan manfaat lainnya

Untuk melakukan analisis laba kotor, diperlukan berbagai data perusahaan. Data yang dibutuhkan untuk menganalisis laba kotor yaitu :

a. Target yang telah ditetapkan, yaitu jumlah angka atau presentase yang telah ditetapkan sebelumnya oleh manajemen.

b. Pencapaian hasil laba pada periode tersebut, artinya laba aktual yang diperoleh pada periode ini. Dengan demikian, laba periode ini, dapat untuk mengetahui apakah sama dengan yang ditargetkan sebelumnya.

c. Laba pada beberapa periode sebelumnya, merupakan perolehan laba beberapa periode yang lalu, lebih dari satu periode ke belakang. Data laba pada beberapa periode sebelumnya sebaiknya diambil lebih dari tiga tahun. Kegunaanya adalah untuk melihat trend perjalanan laba perusahaan dari periode ke periode.

Analisis laba kotor akan banyak membantu manajemen dalam melakukan tindakan apa yang akan diambil ke depan dengan kondisi yang terjadi sekarang atau untuk mengevaluasi apa penyebab turun atau naiknya laba kotor tersebut sehingga target tidak tercapai. Dengan demikian, analisis laba kotor memberikan manfaat yang cukup banyak bagi pihak manajemen.

Untuk tujuan analisis laba kotor ini perlu ditetapkan dasar sebagai faktor pembanding baik bersumber dari data akuntansi yang lampau atau tahun tertentu yang dipilih maupun berupa standar atau anggaran harga biaya produksi produk yang akan dijual. Analisis laba kotor dapat dihitung melalui pendekatan dengan beberapa metode sebagai berikut :

a. Analisis laba kotor berdasarkan data historis

Untuk menguraikan analisis atas dasar data historis atau periode sebelumnya, maka diperlukan data-data akuntansi yang berkaitan dengan laporan hasil usaha periode sebelumnya dan kemudian diperbandingkan dengan laporan hasil usaha periode berjalan.

b. Analisis laba kotor berdasarkan biaya standar dan anggaran 
Untuk menguraikan analisa laba kotor berdasarkan biaya standar dan anggaran laporan hasil usaha dengan metode biaya standar, di perbandingkan dengan laporan hasil hasil usaha aktual pada periode tahun berjalan.

Untuk melakukan menganalisis laba kotor, diperlukan tahap-tahap analisis. Tujuannya adalah di samping memudahkan dalam menganalisis, juga mempermudah dalam memahaminya. Adapun tahap-tahap analisis menurut Kasmir (2016:314) adalah sebagai berikut :

1. Membuat tabel perubahan

2. Menganalisis sebab-sebab perubahan :

a) Perubahan harga jual, yaitu adanya perubahan antara harga jual yang sesungguhnya dengan harga jual yang dianggarkan atau harga jual tahun sebelumnya.

\section{Perubahan Harga Jual $=$ Qt2 $(\operatorname{Pr} 2-\operatorname{Pr} 1)$}

Keterangan :

Qt2 = Jumlah produk yang dijual sesungguhnya

Pr1 = Harga tahun sebelumnya atau yang dianggarkan

Pr2 = Harga yang sesungguhnya

b) Perubahan kuantitas penjualan, yaitu adanya perbedaan antara kuantitas produk direncanakan tahun sebelumnya dengan kuantitas produk yang sesungguhnya.

Perubahan Kuantitas Penjualan $=$ Pr1 $($ Qt2 - Qt1 $)$

Keterangan :

Pr1 = Harga tahun sebelumnya atau yang dianggarkan

Qt1 = Jumlah produk sebelumnya atau yang dianggarkan

Qt2 = Jumlah produk yang dijual sesungguhnya

c) Perubahan harga pokok penjualan, yaitu perbedaan antara harga pokok penjualan per satuan produk yang dianggarkan atau tahun sebelumnya dengan harga pokok yang sesungguhnya.

Perubahan Harga Pokok Penjualan = Qt2 $($ Hpp2 - Hpp1 $)$

Qt2= Jumlah produk yang dijual sesungguhnya

Hpp1 = Harga pokok penjualan sebelumnya atau dianggarkan

Hpp2 = Harga pokok penjualan yang sesungguhnya

d) Perubahan kuantitas harga pokok penjualan, yaitu adanya perubahan harga pokok penjualan karena adanya perubahan / volume yang dijual atau yang diproduksi.

Perubahan Kuantitas Harga Pokok Penjualan = Hpp1 (Qt2 - Qt1)

Keterangan :

Hpp1 = Harga pokok penjualan sebelumnya atau dianggarkan

Qt1 = Jumlah produk sebelumnya atau yang dianggarkan

Qt2= Jumlah produk yang dijual sesungguhnya

3. Membuat laporan perubahan laba rugi.

\section{Harga Jual}

a. Pengertian harga jual

Menurut Mulyadi (2005:65) dalam, harga jual adalah harga yang dapat menutup semua biaya (biaya produksi dan non produksi) ditambah dengan laba yang wajar, umumnya biaya tidak menentukan harga jual produk atau jasa.

Dalam membeli sebuah produk konsumen akan dihadapkan pada varian harga yang berbeda-beda, walau semua mutu produknya hampir sama. Kepuasan 
pembeli/pelanggan adalah hal yang utama pada proses terjadinya jual beli. Namun yang menjadi keterbatasannya adalah harga tertera dalam setiap produk/layanan yang ditawarkan. Harga merupakan nilai tukar suatu barang atau jasa. Sedangkan, harga jual adalah sejumlah kompensasi yang dibutuhkan untuk mendapatkan sejumlah kombinasi barang atau jasa. Perusahaan selalu menetapkan harga produknya dengan harapan produk tersebut laku terjual dan dapat memberikan laba yang maksimal.

b. Faktor-faktor yang mempengaruhi harga jual

Ada beberapa faktor yang harus diperhatikan dalam menentukan harga jual dari suatu barang atau jasa yang diproduksi, yaitu :

1. Faktor biaya, merupakan dasar dalam menentukan harga jual produk atau jasa. Biaya dapat langsung diidentifikasi kepada produk atau jasa yang dihasilkan karena merupakan faktor yang berasal dari dalam perusahaan. Biaya dapat memberikan informasi batas bawah suatu harga yang harus ditentukan oleh perusahaan atas suatu produk atau jasa. Batas bawah harga tersebut haruslah harga yang dapat menutupi seluruh biaya produksi walaupun dengan perolehan laba yang minimal.

2. Faktor bukan biaya, merupakan faktor yang berasal dari luar perusahaan yang dapat mempengaruhi keputusan manajemen dalam menentukan harga jual produk atau jasa. Faktor ini tidak sepenuhnya dapat dikendalikan perusahaan karena faktor tersebut merupakan kegiatan yang bersifat timbal balik antara perusahaan dengan pasar. Berikut ini faktor-faktor tersebut antara lain :

1) Keadaan perekonomian, perubahan kondisi perekonomian suatu negara seperti perubahan inflasi dan deflasi dapat mempengaruhi harga suatu barang atau jasa yang diperjual-belikan di masyarakat.

2) Permintaan dan penawaran pasar, permintaan merupakan jumlah barang atau jasa yang diinginkan oleh konsumen di pasar pada tingkat harga beli tertentu, sedangkan penawaran adalah total barang atau jasa yang ditawarkan oleh produsen di pasar pada tingkat harga jual tertentu. Oleh karena itu, permintaan konsumen terhadap suatu barang atau jasa harus dipertemukan dengan penawaran pasar sehingga terbentuk suatu harga keseimbangan di mana harga tersebut merupakan harga jual tertentu yang diinginkan perusahaan dan juga merupakan harga yang sesuai dengan permintaan konsumen.

3) Elastisitas permintaan, elastisitas permintaan adalah kepekaan perubahan permintaan akan barang atau jasa terhadap perubahan harga. Elastisitas ini membantu manajer untuk memahami apakah suatu bentuk permintaan itu elastis atau inelastis. Elastis berarti perubahan sekian persen pada harga menyebabkan perubahan persentase permintaan yang lebih besar, sedangkan inelastis berarti perubahan sekian persen pada harga secara relatif sedikit mengubah persentase permintaan.

4) Tipe pasar, ada empat jenis struktur pasar yaitu pasar persaingan sempurna, persaingan monopolistik,oligopoli, dan monopoli. Pasar-pasar ini memiliki perbedaan dalam jumlah pembeli dan penjual, tingkat keunikan produk atau jasa yang dihasilkan, seberpa besar rintangan untuk memasuki pasar, dan biaya khusus yang harus dikeluarkan.

5) Pengawasan pemerintah, pengawasan pemerintah biasanya dilakukan untuk mengontrol besaran harga barang atau jasa yang beredar dimasyarakat agar tetap sesuai dengan keinginan perusahaan dan kemampuan masyarakat.

6) Citra atau kesan masyarakat, semakin tinggi citra suatu produk di masyarakat akan menyebabkan produsen menetapkan harga jual yang tinggi. 
7) Tanggung jawab sosial perusahaan, penentuan harga jual barang atau jasa suatu perusahaan juga dapat dipengaruhi oleh rasa tanggung jawab perusahaan terhadap masyarakat. Hal ini dikarenakan tujuan didirikannya perusahaan bukan hanya untuk mencari laba tetapi juga untuk melayani atau memenuhi kebutuhan masyarakat.

8) Tujuan non laba (nirlaba), pada organisasi non laba (nirlaba), laba bukan merupakan tujuan utama berdirinya organisasi tersebut tetapi bertujuan untuk melayani masyarakat agar tingkat kehidupannya non laba berupa jasa yang harga jual produknya ditentukan sama dengan total biaya yang dikeluarkan oleh perusahaan untuk menghasilakan produk tersebut.

c. Sasaran penetapan harga jual

Menurut Boone dan Kurtz (2002:70) dalam Magdalena Hutajulu (2007:8), ada empat kategori dasar atau sasaran penetapan harga, yaitu :

\section{Sasaran Profitabilitas}

Sebagian besar perusahaan mengejar sejumlah sasaran profitabilitas dalam strategi penetapan harganya. Para pemasar mengerti bahwa laba diperoleh dari selisih pendapatan dan beban. Dan juga pendapatan merupakan harga jual dikalikan dengan jumlah yang terjual. Berbagai teori ekonomi mendasari prinsip maksimalisasi keuntungan (profit maximization). Akan tetapi pada kenyatannya prinsip ini masih sulit diterapkan. Maka banyak perusahaan beralih pada sasaran profitabilitas yang lebih sederhana, yaitu Target Return Goal, dimana perusahaan menetapkan harga dengan tingkat profitabilitas yang diinginkan sebagai pengembalian finansial atas penjualan ataupun investasi.

2. Sasaran Volume

Pendekatan yang lain dalam strategi penetapan harga disebut maksimalisasi penjualan (sales maximization), para manajer menetapkan tingkat minimum profitabilitas yang dapat diterima dan kemudian menetapkan harga yang akan mengahasilkan volume penjualan tertinggi tanpa menyebabkan laba turun di bawah level itu. Strategi ini memandang ekspansi penjualan sebagai suatu prioritas yang lebih penting bagi posisi persaingan jangka panjang perusahaan daripada laba jangka pendek.

3. Tingkat Kompetisi

Sasaran penetapan harga ini hanyalah untuk menyamakan harga dengan pesaing. Jadi perusahaan berusaha untuk menghindari perang harga dengan tidak menekankan elemen harga dari bauran pemasaran dan memfokuskan usaha persaingannya pada variabel selain harga seperti menambah nilai, meningkatkan kualitas, mendidik konsumen, dan menciptakan hubungan.

4. Sasaran Pretisi

Pengaruh harga pada prestise membuat sebuah harga menjadi relatif tinggi untuk mengembangkan dan menjaga sebuah citra dari kualitas dan eksklusivitas. Para pemasar menetapkan sasaran tersebut karena mereka mengakui peran harga dalam mengkomunikasikan citra suatu perusahaan dan produk-produknya.

d. Metode Penetapan Harga Jual

Menurut Herman (2006) ada beberapa metode penetapan harga (methods of price determination) yang dapat dilakukan budgeter dalam perusaahaan, yaitu: 
1. Metode taksiran (judgmental method), metode ini biasa digunakan oleh persuhaan yang baru saja berdiri karena dilakukan dengan menggunakan prediksi tanpa menggunakan data statistik. Oleh karena itu kekurangan dari metode ini adalah tingkat keakuratan prediksi sangat rendah.

2. Metode berbasis pasar (market-based pricing)

a. Harga pasar saat ini (current market price), metode ini dipakai apabila perusahaan mengeluarkan produk baru, yaitu hasil modifikasi dari produk yang lama. Perusahaan akan menetapkan produk baru baru tersebut seharga dengan produk yang lama. Penggunaan metode ini murah dan cepat. Akan tetapi pangsa pasar yang didapat pada tahun pertama relatif kecil karena konsumen belum mengetahui profil produk baru perusahaan tersebut.

b. Harga pesaing (competitor price), metode ini menetapkan harga produknya dengan mereplikasi langsung harga produk perusahaan saingannya untuk produk yang sama atau berkaitan. Dengan metode perusahaan berpotensi mengalami kehilangan pangsa pasar karena dianggap sebagai pemalsu. Ini dapat terjadi apabila produk perusahaan tidak mampu menyaingi produk pesaing.

c. Harga pasar yang disesuaikan (adjusted current marker price), penyesuaian dapat dilakukan berdasarkan pada faktor eksternal dan internal. Dengan metode ini, perusahaan mengidentifikasi harga pasar yang berlaku pada saat penyiapan anggaran dengan melakukan survey pasar atau memperoleh data sekunder. Harga yang berlaku tersebut dikalikan dengan penyesuaian (price adjustment) setelah mempertimbangkan faktor internal dan eksternal yang ditetapkan dalam angka indeks (persentase).

3. Metode berbasis biaya (cost-based pricing)

a. Biaya penuh plus tambahan tertentu (full cost plus mark-up), dalam metode ini budgeter harus mengetahui berapa proyeksi full cost untuk produk tertentu. Full cost adalah seluruh biaya yang dikeluarkan dan atau dibebankan sejak bahan baku mulai diproses sampai produk siap untuk dijual. Hasil penjumlahan antara full cost dengan tingkat keuntungan yang diharapkan (required profit margin) yang ditentukan oleh direktur pemasaran atau personalia yang diberikan wewenang dalam penetapan harga, akan membentuk proyeksi harga untuk produk itu pada tahun anggaran mendatang. Required profit margin dapat juga ditetapkan dalam presentase. Untuk menetapkan profit, budgeter harus mengalikan full cost dengan persentase required profit margin. Penjumlahan antara profit dengan full cost akan menghasilkan proyeksi harga.

b. Biaya variabel plus tambahan (variable cost plus mark-up). Dengan metode ini budgeter menggunakan basis variable cost. Proyeksi harga diperoleh dengan menambahkan mark-up laba yang di inginkan. Markup yang diinginkan pada metode ini lebih tinggi dari mark-up dengan basis full cost. Hal ini disebabkan biaya variabel selalu lebih rendah daripada full cost. 
e. Tujuan Penatapan Harga

Penetapan harga suatu produk atau jasa tergantung dari tujuan perusahaan atau penjual yang memasarkan produk tersebut. Menurut Harini 2008 penetapan harga memiliki tujuan yaitu:

1. Penetapan harga suatu produk memiliki tujuan untuk mecapai target perusahaan untuk memperoleh penghasilan serta memdapatkan target investasi yang sudah ditentukan prosentase keuntungannya, sehingga untuk memenuhi hal tersebut diperlukan adanya penetapan harga pasti dari suatu produk yang telah diproduksi perusahaan.

2. Fungsi penetapan harga yang kedua merupakan hal yang harus diperhatikan untuk kestabilan harga suatu produk.

3. Penetapan harga dilakukan oleh perusahaan untuk mempertahankan produk dalam peredaran pasar, sehingga produk tetap dapat bertahan dipasaran.

4. Penetapan harga harus dilakukan untuk mencegah terjadiya persaingan dengan perusaan lain yang memiliki produk yang hampir sama.

5. Perusahaan menetapkan harga untuk menentukan laba yang akan didapat oleh perusahaan agar perusahaan tetap dapat memproduksi suatu barang yang akan dipasarkan.

Machfoedz (2005:136) juga berpendapat "Tujuan dari penetapan suatu harga adalah utuk mencapai target perusaan, mendapatkan laba dari penjualan, meningkatkan serta mengembangkan produksi produk, serta meluaskan target pemasaran.

\section{Analisis Laba Kotor dalam Menentukan Harga Jual}

Analisis laba kotor merupakan salah satu alat analisis terhadap laba yang tertuang di dalam laporan laba rugi. Analisis laba kotor ini berguna untuk mengukur tingkat laba yang diperoleh perusahaan dengan membandingkan antara laba sesungguhnya dengan laba yang dianggarkan. Ketika terjadi selisih kurang atau selisih lebih, tentu perusahaan harus menganalisanya lebih lanjut.

Perubahan laba kotor terjadi karena faktor harga jual per satuan produk, faktor kuantitas produk yang dapat dijual, dan faktor harga pokok penjualan. Ketiga faktor tersebut termasuk dalam perhitungan analisis laba kotor.

Perubahan harga jual tentu akan sangat berpengaruh terhadap laba kotor. Jadi, dengan adanya analisis laba kotor perusahaan dapat mengetahui naik turunnya harga jual dan tentu akan sangat membantu pihak manajemen dalam mengevaluasi penyebab terjadinya perubahan harga jual.

Dengan diketahuinya penyebab naik turunnya harga, pihak manajamen dapat memprediksi berbagai hal, terutama berkaitan dengan penentuan harga jual ke depan dan target harga jual yang lebih realistis. Kesalahan akibat penentuan harga jual ini pasti dikarenakan faktor perubahan harga jual yang sangat rentan terhadap perubahan di luar lingkungan perusahaan.

Misalnya apabila terdapat pesaing baru dengan kualitas barang yang sama dengan produk kita, tetapi memberikan harga jual yang lebih murah, hal tersebut juga akan memengaruhi nilai penjualan perusahaan tentunya. Demikian pula jika produk yang sejenis di luar berkurang, perusahaan dapat menaikkan harga jual yang diinginkan. Oleh karena itu pihak manajemen dapat menggunakan analisis laba kotor sebagai salah satu alat dalam menentukan harga jual. 


\section{Kerangka Konsep}

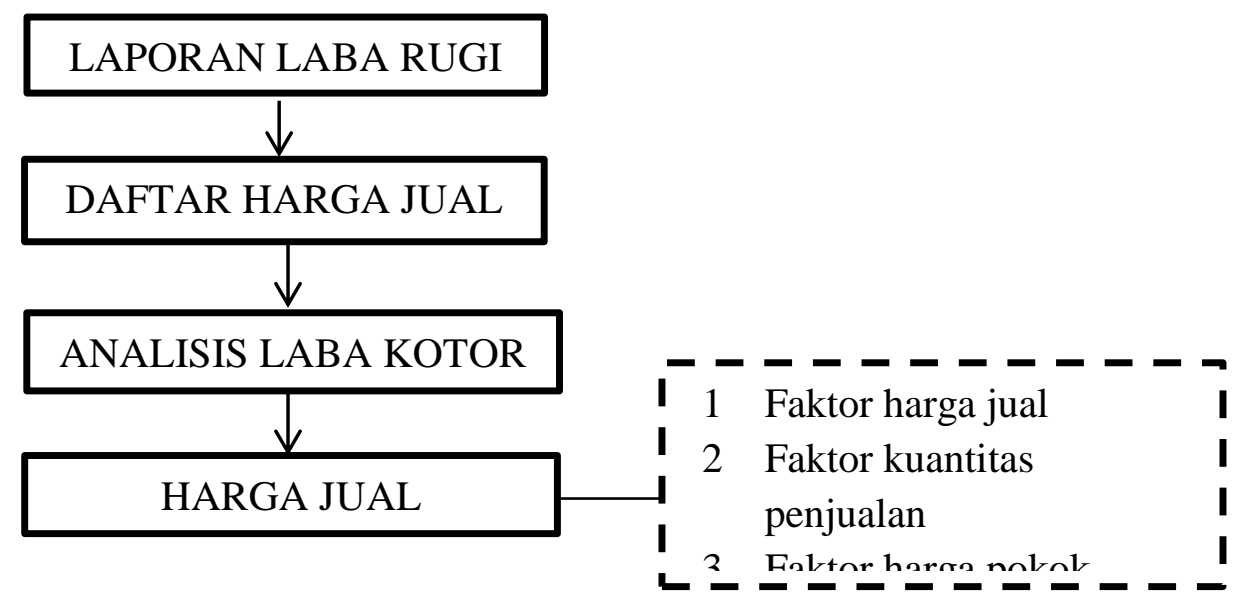

\section{Analisis Hasil Penelitian}

Diketahui bahwa perusahaan QMart merupakan perusahaan dagang yang menjual \pm 64.607 produk. Sehingga dalam melakukan analisis penulis hanya akan 10 produk Indofood untuk di jadikan sebagai sampel. Berikut daftar harga beserta kuantitas penjualan 10 produk Indofood. Dengan asumsi fluktuasi harga 1 tahun diabaikan.

Tabel 1

Rekapitulasi Harga Jual (Dalam Rp)

\begin{tabular}{|l|r|r|r|r|r|}
\hline \multirow{2}{*}{ Nama Barang } & \multicolumn{5}{c|}{ Harga Jual (Dalam Rp) } \\
\cline { 2 - 6 } & \multicolumn{1}{|c|}{$\mathbf{2 0 1 3}$} & \multicolumn{1}{c|}{$\mathbf{2 0 1 4}$} & \multicolumn{1}{c|}{$\mathbf{2 0 1 5}$} & \multicolumn{1}{c|}{$\mathbf{2 0 1 6}$} & \multicolumn{1}{c|}{$\mathbf{2 0 1 7}$} \\
\hline \hline Sun BC Beras Merah 8x20gr & $5.000,00$ & $5.750,00$ & $6.000,00$ & $7.000,00$ & $7.850,00$ \\
\hline Indomilk Full Cream 800Gr & $55.800,00$ & $63.300,00$ & $66.326,00$ & $67.600,00$ & $69.250,00$ \\
\hline Bimoli Clasic 5 Ltr & $61.750,00$ & $68.750,00$ & $74.400,00$ & $70.000,00$ & $77.250,00$ \\
\hline La Fonte Spaghetti 500 Gr & $9.990,00$ & $11.325,00$ & $11.800,00$ & $13.200,00$ & $14.700,00$ \\
\hline Chitato Beef Barbeque 68Gr & $6.900,00$ & $7.450,00$ & $8.150,00$ & $8.600,00$ & $9.500,00$ \\
\hline Promina Biscuit Susu 130 Gr & $9.950,00$ & $10.570,00$ & $11.000,00$ & $11.450,00$ & $12.300,00$ \\
\hline Qtela Original 185 Gr & $8.599,00$ & $9.100,00$ & $9.750,00$ & $10.200,00$ & $10.650,00$ \\
\hline Happy Salad Pure Soya Oil 51 & $126.000,00$ & $130.600,00$ & $136.800,00$ & $139.500,00$ & $142.700,00$ \\
\hline Bu Krim Oxy Klin Higienis 750Gr & $14.900,00$ & $15.300,00$ & $16.500,00$ & $17.600,00$ & $18.650,00$ \\
\hline Indomilk Instant 400 Gr & $25.000,00$ & $28.950,00$ & $29.990,00$ & $33.400,00$ & $35.100,00$ \\
\hline
\end{tabular}

Sumber : Daftar Harga Jual QMART Superstore Periode 2013 - 2017

Tabel 2

Rekapitulasi Harga Pokok Penjualan (Dalam Rp)

\begin{tabular}{|l|r|r|r|r|r|}
\hline \multirow{2}{*}{ Nama Barang } & \multicolumn{5}{|c|}{ Harga Pokok Penjualan (Dalam Rp) } \\
\cline { 2 - 6 } & \multicolumn{1}{|c|}{$\mathbf{2 0 1 3}$} & \multicolumn{1}{c|}{$\mathbf{2 0 1 4}$} & \multicolumn{1}{c|}{$\mathbf{2 0 1 5}$} & \multicolumn{1}{c|}{$\mathbf{2 0 1 6}$} & \multicolumn{1}{c|}{$\mathbf{2 0 1 7}$} \\
\hline \hline Sun BC Beras Merah 8x20gr & $4.370,00$ & $5.750,00$ & $5.350,00$ & $6.250,00$ & $7.098,05$ \\
\hline Indomilk Full Cream 800Gr & $47.528,00$ & $63.300,00$ & $58.025,00$ & $59.150,00$ & $60.593,00$ \\
\hline Bimoli Clasic 5 Ltr & $54.150,00$ & $68.750,00$ & $64.100,00$ & $61.250,00$ & $67.593,00$ \\
\hline La Fonte Spaghetti 500 Gr & $8.741,00$ & $11.325,00$ & $10.225,00$ & $11.375,00$ & $12.800,00$ \\
\hline Chitato Beef Barbeque 68Gr & $6.037,00$ & $7.450,00$ & $7.131,00$ & $7.625,00$ & $8.312,00$ \\
\hline Promina Biscuit Susu 130 Gr & $8.850,00$ & $9.440,00$ & $9.850,00$ & $10.320,00$ & $11.167,00$ \\
\hline Qtela Original 185 Gr & $7.600,00$ & $8.112,00$ & $8.677,00$ & $9.210,00$ & $9.666,00$ \\
\hline
\end{tabular}




\begin{tabular}{|l|r|r|r|r|r|} 
Happy Salad Pure Soya Oil 51 & $117.916,00$ & $122.540,00$ & $128.517,00$ & $131.420,00$ & $134.616,00$ \\
\hline Bu Krim Oxy Klin Higienis 750Gr & $13.205,00$ & $13.509,00$ & $14.800,00$ & $15.901,00$ & $16.955,00$ \\
\hline Indomilk Instant 400 Gr & $24.450,00$ & $28.300,00$ & $29.400,00$ & $32.720,00$ & $34.560,00$ \\
\hline
\end{tabular}

Sumber : Daftar Harga Jual QMART Superstore Periode 2013 - 2017

Tabel 3

Rekapitulasi Laba Kotor (Dalam Rp)

\begin{tabular}{|l|c|c|c|c|c|}
\hline \multirow{2}{*}{ Nama Barang } & \multicolumn{5}{c|}{ Laba Kotor (Dalam Rp) } \\
\cline { 2 - 6 } & $\mathbf{2 0 1 3}$ & $\mathbf{2 0 1 4}$ & $\mathbf{2 0 1 5}$ & $\mathbf{2 0 1 6}$ & $\mathbf{2 0 1 7}$ \\
\hline \hline Sun BC Beras Merah 8x20gr & $94.500,00$ & $98.800,00$ & $100.750,00$ & $112.500,00$ & $112.040,00$ \\
\hline Indomilk Full Cream 800Gr & $818.928,00$ & $868.350,00$ & $630.876,00$ & $701.350,00$ & $796.444,00$ \\
\hline Bimoli Clasic 5 Ltr & $478.800,00$ & $568.425,00$ & $710.700,00$ & $700.000,00$ & $454.250,00$ \\
\hline La Fonte Spaghetti 500 Gr & $126.149,00$ & $140.184,00$ & $137.025,00$ & $133.225,00$ & $140.600,00$ \\
\hline Chitato Beef Barbeque 68Gr & $37.109,00$ & $62.444,00$ & $64.197,00$ & $47.775,00$ & $61.776,00$ \\
\hline Promina Biscuit Susu 130 Gr & $72.600,00$ & $62.150,00$ & $70.150,00$ & $67.800,00$ & $69.113,00$ \\
\hline Qtela Original 185 Gr & $119.880,00$ & $132.392,00$ & $138.417,00$ & $129.690,00$ & $124.968,00$ \\
\hline Happy Salad Pure Soya Oil 51 & $153.596,00$ & $161.200,00$ & $140.811,00$ & $121.200,00$ & $185.932,00$ \\
\hline Bu Krim Oxy Klin Higienis 750Gr & $72.885,00$ & $69.849,00$ & $64.600,00$ & $59.465,00$ & $61.020,00$ \\
\hline Indomilk Instant 400 Gr & $17.600,00$ & $18.850,00$ & $27.990,00$ & $38.760,00$ & $30.240,00$ \\
\hline
\end{tabular}

Tabel 4

Rekapitulasi Kuantitas Penjualan (UNIT)

\begin{tabular}{|l|c|c|c|c|c|}
\hline \multirow{2}{*}{ Nama Barang } & \multicolumn{5}{c|}{ Kuantitas Penjualan (UNIT) } \\
\cline { 2 - 6 } & $\mathbf{2 0 1 3}$ & $\mathbf{2 0 1 4}$ & $\mathbf{2 0 1 5}$ & $\mathbf{2 0 1 6}$ & $\mathbf{2 0 1 7}$ \\
\hline \hline Sun BC Beras Merah 8x20gr & 150 & 152 & 155 & 150 & 149 \\
\hline Indomilk Full Cream 800Gr & 99 & 105 & 76 & 83 & 92 \\
\hline Bimoli Clasic 5 Ltr & 63 & 65 & 69 & 80 & 79 \\
\hline La Fonte Spaghetti 500 Gr & 101 & 99 & 87 & 73 & 74 \\
\hline Chitato Beef Barbeque 68Gr & 43 & 67 & 63 & 49 & 52 \\
\hline Promina Biscuit Susu 130 Gr & 66 & 55 & 61 & 60 & 61 \\
\hline Qtela Original 185 Gr & 120 & 134 & 129 & 131 & 127 \\
\hline Happy Salad Pure Soya Oil 51 & 19 & 20 & 17 & 15 & 23 \\
\hline Bu Krim Oxy Klin Higienis 750Gr & 43 & 39 & 38 & 35 & 36 \\
\hline Indomilk Instant 400 Gr & 32 & 29 & 46 & 57 & 56 \\
\hline
\end{tabular}

Sumber : Daftar Harga Jual QMART Superstore Periode 2013 - 2017

Tabel 5

Rekapitulasi Persediaan (UNIT)

\begin{tabular}{|l|c|c|c|c|c|}
\hline \multirow{2}{*}{ Nama Barang } & \multicolumn{5}{|c|}{ Persediaan (UNIT) } \\
\cline { 2 - 6 } & $\mathbf{2 0 1 3}$ & $\mathbf{2 0 1 4}$ & $\mathbf{2 0 1 5}$ & $\mathbf{2 0 1 6}$ & $\mathbf{2 0 1 7}$ \\
\hline \hline Sun BC Beras Merah 8x20gr & 170 & 170 & 170 & 170 & 170 \\
\hline Indomilk Full Cream 800Gr & 100 & 110 & 100 & 100 & 100 \\
\hline Bimoli Clasic 5 Ltr & 70 & 70 & 70 & 100 & 100 \\
\hline
\end{tabular}




\begin{tabular}{|l|c|c|c|c|c|} 
La Fonte Spaghetti 500 Gr & 110 & 110 & 110 & 100 & 90 \\
\hline Chitato Beef Barbeque 68Gr & 50 & 70 & 70 & 70 & 60 \\
\hline Promina Biscuit Susu 130 Gr & 70 & 60 & 65 & 70 & 65 \\
\hline Qtela Original 185 Gr & 150 & 150 & 135 & 135 & 130 \\
\hline Happy Salad Pure Soya Oil 51 & 20 & 30 & 25 & 20 & 25 \\
\hline Bu Krim Oxy Klin Higienis 750Gr & 50 & 50 & 40 & 40 & 40 \\
\hline Indomilk Instant 400 Gr & 37 & 35 & 50 & 60 & 60 \\
\hline
\end{tabular}

Sumber : Daftar Persediaan QMART Superstore Periode 2013 - 2017

Dalam menganalisis laba kotor akan digunakan 2 metode, yaitu :

1. Dengan membandingkan data dari salah satu tahun yang dipilih sebagai tahun dasar dengan data dari tahun yang dianalisis.

2. Dengan menggunakan anggaran (budget) yang telah disusun dan dibandingkan dengan data dari tahun yang akan dianalisis.

Namun perusahaan QMart tidak menetapkan anggaran penjualan pada masa mendatang, maka penulis hanya mengambil satu metode saja, yakni metode tahun dasar sebagai alat untuk menganalisis laba kotor dengan membandingkan antara tahun 2013 dengan tahun 2014, tahun 2014 dengan tahun 2015, tahun 2015 dengan tahun 2016, serta tahun 2016 dengan tahun 2017.

Untuk memperjelas perhitungan, berikut rumus beserta keterangan yang digunakan penulis :

a. Perubahan Harga Jual = Qt2 $(\operatorname{Pr} 2-\operatorname{Pr} 1)$

b. Perubahan Kuantitas Penjualan $=\operatorname{Pr} 1(\mathrm{Qt} 2-\mathrm{Qt} 1)$

c. Perubahan Harga Pokok = Qt2 (Hpp2 - Hpp1)

d. Perubahan Kuantitas Harga Pokok = Hpp1 (Qt2 - Qt1)

Keterangan :

Qt1 = Jumlah produk yang dijual pada tahun sebelumnya

Qt2 = Jumlah produk yang dijual sesungguhnya

Pr1 = Harga jual pada tahun sebelumnya

Pr2 = Harga jual yang sesungguhnya

Hpp1 = Harga pokok penjualan pada tahun sebelumnya

Hpp2 = Harga pokok penjualan yang sesungguhnya

\section{Analisis Laba Kotor Sun BC Beras Merah 8x20gr (Tahun 2013 - 2017)}

Tabel 6

Daftar Perubahan laba kotor Sun BC Beras Merah Tahun 2013 - 2014

\begin{tabular}{|l|rr|rr|rr|}
\hline \multicolumn{1}{|c|}{ Komponen } & \multicolumn{2}{c|}{2013} & \multicolumn{2}{c|}{2014} & \multicolumn{2}{c|}{ Naik/(Turun) } \\
\hline Penjualan bersih & $\mathrm{Rp}$ & $750.000,00$ & $\mathrm{Rp}$ & $874.000,00$ & $\mathrm{Rp}$ & $124.000,00$ \\
\hline Harga pokok penjualan & $\mathrm{Rp}$ & $655.500,00$ & $\mathrm{Rp}$ & $775.200,00$ & $\mathrm{Rp}$ & $119.700,00$ \\
\hline Laba kotor & $\mathrm{Rp}$ & $94.500,00$ & $\mathrm{Rp}$ & $98.800,00$ & $\mathrm{Rp}$ & $4.300,00$ \\
\hline Jumlah barang yang dijual & & 150 unit & & 152 unit & 2 unit \\
\hline Harga per satuan & $\mathrm{Rp}$ & $5.000,00$ & $\mathrm{Rp}$ & $5.750,00$ & $\mathrm{Rp}$ & 750,00 \\
\hline Harga pokok per satuan & $\mathrm{Rp}$ & $4.370,00$ & $\mathrm{Rp}$ & $5.100,00$ & $\mathrm{Rp}$ & 730,00 \\
\hline
\end{tabular}

Sumber data : data olahan 
Berdasarkan tabel 6 yaitu tahun 2014 dibandingkan dengan tahun 2013 menunjukkan adanya kenaikan dalam penjualan yaitu sebesar Rp.124.000,00 dan kenaikan harga pokok penjualan sebesar Rp.119.700,00 sehingga mengalami kenaikan laba kotor sebesar Rp.4.300,00. Hal ini disebabkan oleh beberapa faktor, berikut analisisnya.

a. Faktor harga jual

Rumus : Qt2 (Pr2 - Pr1)

$152(\operatorname{Rp} 5.750-\operatorname{Rp} 5.000)=\operatorname{Rp~114.000,00~}$

b. Faktor jumlah kuantitas penjualan

Rumus : Pr1 (Qt2 - Qt1)

Rp5.000 (152-150) = Rp 10.000,00

c. Faktor harga pokok per unit

Rumus : Qt2 (Hpp2 - Hpp1)

$152(\operatorname{Rp} 5.100-\operatorname{Rp} 4.370)=\operatorname{Rp} 110.960,00$

d. Faktor kuantitas harga pokok

Rumus : Hpp1 (Qt2 - Qt1)

Rp4.370 (152 - 150) = Rp 8.740,00

Tabel 7

Laporan Perubahan laba kotor Sun BC Beras Merah Tahun 2013 - 2014

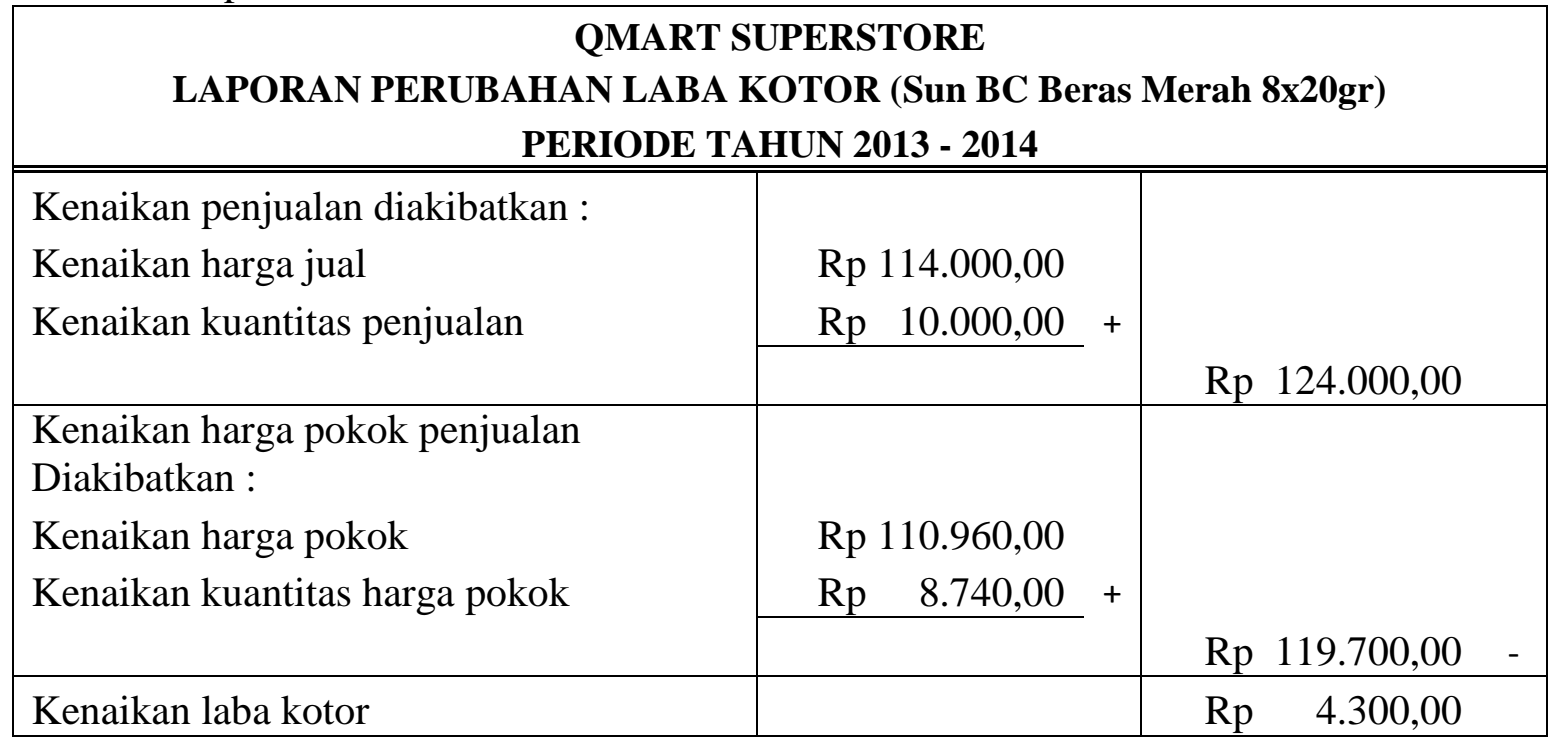

Sumber : Data Olahan

Berdasarkan laporan perubahan laba kotor, pada tahun 2013 - 2014 terjadi kenaikan harga jual sebesar Rp.114.000,00, kenaikan kuantitas penjualan sebesar Rp.10.000,00, kenaikan harga pokok sebesar Rp.110.960,00, dan kenaikan kuantitas harga pokok sebesar Rp.8.740,00. Sehingga memicu kenaikan laba kotor sebesar Rp4.300,00.

Tabel 8

Daftar Perubahan laba kotor Sun BC Beras Merah Tahun 2014 - 2015

\begin{tabular}{|l|rr|rr|rr|}
\hline \multicolumn{1}{|c|}{ Komponen } & \multicolumn{2}{|c|}{2014} & \multicolumn{2}{c|}{2015} & \multicolumn{2}{c|}{ Naik/(Turun) } \\
\hline Penjualan bersih & $\mathrm{Rp}$ & $874.000,00$ & $\mathrm{Rp}$ & $930.000,00$ & $\mathrm{Rp}$ & $56.000,00$ \\
\hline Harga pokok penjualan & $\mathrm{Rp}$ & $775.200,00$ & $\mathrm{Rp}$ & $829.250,00$ & $\mathrm{Rp}$ & $54.050,00$ \\
\hline Laba kotor & $\mathrm{Rp}$ & $98.800,00$ & $\mathrm{Rp}$ & $100.750,00$ & $\mathrm{Rp}$ & $1.950,00$ \\
\hline Jumlah barang yang dijual & & 152 unit & & 155 unit & & 3 unit \\
\hline Harga per satuan & $\mathrm{Rp}$ & $5.750,00$ & $\mathrm{Rp}$ & $6.000,00$ & $\mathrm{Rp}$ & 250,00 \\
\hline Harga pokok per satuan & $\mathrm{Rp}$ & $5.100,00$ & $\mathrm{Rp}$ & $5.350,00$ & $\mathrm{Rp}$ & 250,00 \\
\hline
\end{tabular}




\section{Sumber data : data olahan}

Berdasarkan tabel 8 yaitu tahun 2015 dibandingkan dengan tahun 2014 menunjukkan adanya kenaikan dalam penjualan yaitu sebesar Rp.56.000,00 dan kenaikan harga pokok penjualan sebesar Rp.54.050,00 sehingga mengalami kenaikan laba kotor sebesar Rp.1.950,00. Hal ini disebabkan oleh beberapa faktor, berikut analisisnya.

a. Faktor harga jual

Rumus : Qt2 (Pr2 - Pr1)

$155($ Rp6.000 - Rp5.750) $=$ Rp 38.750,00

b. Faktor jumlah kuantitas penjualan

Rumus : Pr1 (Qt2 - Qt1)

Rp5.750 (155 - 152) = Rp 17.250,00

c. Faktor harga pokok per unit

Rumus : Qt2 (Hpp2 - Hpp1)

$155(\operatorname{Rp5} .350-\mathrm{Rp5} .100)=\mathrm{Rp} 38.750,00$

d. Faktor kuantitas harga pokok

Rumus : Hpp1 (Qt2 - Qt1)

Rp5.100 (155 - 152) = Rp 15.300,00

\section{E. Pembahasan Hasil Penelitian}

Sebelumnya penulis akan menampilkan laporan laba rugi keseluruhan dari QMart Superstore pada tahun $2013-2017$.

Tabel 9

Rekapitulasi Laporan Laba Rugi Tahun 2013 - 2017

(Dalam jutaan Rp)

\begin{tabular}{|r|l|r|r|r|r|r|}
\hline No. & Keterangan & $\mathbf{2 0 1 3}$ & $\mathbf{2 0 1 4}$ & \multicolumn{1}{c|}{$\mathbf{2 0 1 5}$} & \multicolumn{1}{c|}{$\mathbf{2 0 1 6}$} & \multicolumn{1}{c|}{$\mathbf{2 0 1 7}$} \\
\hline 1 & Penjualan Bersih & $41.526,2$ & $48.454,3$ & $49.750,4$ & $49.857,2$ & $49.950,7$ \\
\hline 2 & Harga Pokok Penjualan & $(36.468,3)$ & $(42.904,8)$ & $(43.600,4)$ & $(43.850,1)$ & $(43,250,1)$ \\
\hline $\mathbf{3}$ & Laba Kotor & $\mathbf{5 . 0 5 7 , 8}$ & $\mathbf{5 . 9 4 9 , 5}$ & $\mathbf{6 . 1 5 0 , 0}$ & $\mathbf{6 . 0 0 7 , 1}$ & $\mathbf{6 . 7 0 0 , 5}$ \\
\hline 4 & Biaya Adm Penjualan dan Umum & $(2.333,7)$ & $(2.745,7)$ & $(2.981,7)$ & $(2.925,2)$ & $(2.815,0)$ \\
\hline $\mathbf{5}$ & Laba Operasional & $\mathbf{2 . 7 2 4 , 1}$ & $\mathbf{3 . 2 0 3 , 7}$ & $\mathbf{3 . 1 6 8 , 3}$ & $\mathbf{3 . 0 8 1 , 8}$ & $\mathbf{3 . 8 8 5 , 5}$ \\
\hline 6 & Biaya Bunga & $(386,1)$ & $(406,5)$ & $(420,1)$ & $(450,2)$ & $(465,2)$ \\
\hline 7 & Biaya Penyusutan & $(429,2)$ & $(536,6)$ & $(575,6)$ & $(565,2)$ & $(600,2)$ \\
\hline 8 & Biaya Lainnya & $(2,3)$ & $(2,8)$ & $(3,5)$ & $(6,2)$ & $(5,2)$ \\
\hline $\mathbf{9}$ & pendapatan setelah biaya bunga dan & $\mathbf{1 . 9 0 6 , 3}$ & $\mathbf{2 . 2 5 7 , 7}$ & $\mathbf{2 . 1 6 9 , 1}$ & $\mathbf{2 . 0 6 0 , 1}$ & $\mathbf{2 . 8 1 4 , 7}$ \\
\hline 10 & Penghasilan lainnya & 3,4 & 4,2 & 5,6 & 7,5 & 8,0 \\
\hline 11 & Pend. Sebelum Pajak (EBT) & $1.909,7$ & $2.262,0$ & $2.174,7$ & $2.067,6$ & $2.822,7$ \\
\hline 12 & Pajak & $(517,9)$ & $(527,6)$ & $(517,4)$ & $(492,0)$ & $(671,7)$ \\
\hline 13 & Laba bersih & $\mathbf{1 . 3 9 1 , 8}$ & $\mathbf{1 . 7 3 4 , 3}$ & $\mathbf{1 . 6 5 7 , 2}$ & $\mathbf{1 . 5 7 5 , 6}$ & $\mathbf{2 . 1 5 0 , 9}$ \\
\hline
\end{tabular}

Sumber : Laporan Laba Rugi QMart Superstore

Perubahan laba kotor merupakan salah satu pedoman efisiensi dan efektifitas manajemen dalam mengelola suatu unit usaha dalam hubungannya dengan pertumbuhan 
serta perkembangan unit usaha yang dikelolanya. Adapun faktor-faktor yang mempengaruhi perubahan laba kotor adalah jumlah penjualan, perubahan harga jual, perubahan kuantitas (volume) penjualan dan perubahan harga pokok penjualan. Faktorfaktor tersebut harus diperhatikan kenaikan dan penurunannya. Untuk dapat meningkatkan laba kotor dapat ditempuh dengan cara:

1. Mengusahakan kenaikan penjualan yang lebih tinggi daripada harga pokok penjualan.

2. Mengusahakan penurunan harga pokok penjualan yang lebih besar daripada penurunan penjualan.

3. Mengusahakan kenaikan penjualan dan mempertahankan harga pokok.

Setelah menganalisis perubahan laba kotor dari tahun 2013 hingga 2017. Maka dapat diketahui terjadinya kenaikan dan penurunan tiap komponen yang mengakibatkan naik turunnya laba kotor. Berikut hasil analisis laba kotor 5 produk indofood dari tahun 2014 hingga 2017.

Tabel 10

Persentase Perubahan Laba Kotor Tahun 2014

\begin{tabular}{|c|c|c|c|c|c|}
\hline \multirow[b]{2}{*}{ Nama Barang } & \multicolumn{5}{|c|}{2014 (Dibandingkan dengan tahun 2013) } \\
\hline & $\begin{array}{c}\text { HARGA } \\
\text { JUAL }\end{array}$ & $\begin{array}{l}\text { KUANTITAS } \\
\text { PENJUALAN }\end{array}$ & $\begin{array}{l}\text { HARGA } \\
\text { POKOK }\end{array}$ & $\begin{array}{c}\text { KUANTITAS } \\
\text { HARGA POKOK }\end{array}$ & $\begin{array}{c}\text { LABA } \\
\text { KOTOR }\end{array}$ \\
\hline Sun BC Beras Merah 8x20gr & $\begin{array}{l}\text { NAIK } \\
(15 \%)\end{array}$ & $\begin{array}{c}\text { NAIK } \\
(1,33 \%) \\
\end{array}$ & $\begin{array}{c}\text { NAIK } \\
(16,70 \%)\end{array}$ & $\begin{array}{c}\text { NAIK } \\
(1,33 \%) \\
\end{array}$ & $\begin{array}{c}\text { NAIK } \\
(4,55 \%)\end{array}$ \\
\hline Indomilk Full Cream 800Gr & $\begin{array}{c}\text { NAIK } \\
(13,44 \%)\end{array}$ & $\begin{array}{l}\text { NAIK } \\
(6,06 \%)\end{array}$ & $\begin{array}{c}\text { NAIK } \\
(15,78 \%)\end{array}$ & $\begin{array}{l}\text { NAIK } \\
(6,06 \%)\end{array}$ & $\begin{array}{l}\text { NAIK } \\
(6,03 \%)\end{array}$ \\
\hline Bimoli Clasic 5 Ltr & $\begin{array}{c}\text { NAIK } \\
(11,34 \%)\end{array}$ & $\begin{array}{l}\text { NAIK } \\
(3,17 \%)\end{array}$ & $\begin{array}{c}\text { NAIK } \\
(10,81 \%)\end{array}$ & $\begin{array}{l}\text { NAIK } \\
(3,17 \%)\end{array}$ & $\begin{array}{c}\text { NAIK } \\
(18,72 \%)\end{array}$ \\
\hline La Fonte Spaghetti $500 \mathrm{Gr}$ & $\begin{array}{c}\text { NAIK } \\
(13,36 \%) \\
\end{array}$ & $\begin{array}{l}\text { TURUN } \\
(1,98 \%)\end{array}$ & $\begin{array}{c}\text { NAIK } \\
(13,36 \%)\end{array}$ & $\begin{array}{l}\text { TURUN } \\
(1,98 \%)\end{array}$ & $\begin{array}{c}\text { NAIK } \\
(11,13 \%)\end{array}$ \\
\hline Chitato Beef Barbeque $68 \mathrm{Gr}$ & $\begin{array}{l}\text { NAIK } \\
(7,97 \%)\end{array}$ & $\begin{array}{c}\text { NAIK } \\
(55,81 \%)\end{array}$ & $\begin{array}{l}\text { NAIK } \\
(7,97 \%)\end{array}$ & $\begin{array}{c}\text { NAIK } \\
(55,81 \%)\end{array}$ & $\begin{array}{c}\text { NAIK } \\
(68,27 \%)\end{array}$ \\
\hline Promina Biscuit Susu $130 \mathrm{Gr}$ & $\begin{array}{c}\text { NAIK } \\
(6,23 \%)\end{array}$ & $\begin{array}{r}\text { TURUN } \\
(16,67 \%)\end{array}$ & $\begin{array}{l}\text { NAIK } \\
(6,67 \%)\end{array}$ & $\begin{array}{r}\text { TURUN } \\
(16,67 \%)\end{array}$ & $\begin{array}{r}\text { TURUN } \\
(14,39 \%)\end{array}$ \\
\hline Qtela Original $185 \mathrm{Gr}$ & $\begin{array}{c}\text { NAIK } \\
(5,83 \%)\end{array}$ & $\begin{array}{c}\text { NAIK } \\
(11,67 \%)\end{array}$ & $\begin{array}{c}\text { NAIK } \\
(6,74 \%)\end{array}$ & $\begin{array}{c}\text { NAIK } \\
(11,67 \%)\end{array}$ & $\begin{array}{c}\text { NAIK } \\
(10,44 \%)\end{array}$ \\
\hline $\begin{array}{l}\text { Happy Salad Pure Soya Oil } \\
\text { 5L }\end{array}$ & $\begin{array}{c}\text { NAIK } \\
(3,65 \%)\end{array}$ & $\begin{array}{c}\text { NAIK } \\
(5,26 \%)\end{array}$ & $\begin{array}{c}\text { NAIK } \\
(3,92 \%)\end{array}$ & $\begin{array}{c}\text { NAIK } \\
(5,26 \%)\end{array}$ & $\begin{array}{c}\text { NAIK } \\
(4,95 \%)\end{array}$ \\
\hline $\begin{array}{l}\text { Bu Krim Oxy Klin Higienis } \\
\text { 750Gr }\end{array}$ & $\begin{array}{c}\text { NAIK } \\
(2,68 \%)\end{array}$ & $\begin{array}{l}\text { TURUN } \\
(9,30 \%)\end{array}$ & $\begin{array}{c}\text { NAIK } \\
(2,30 \%)\end{array}$ & $\begin{array}{l}\text { TURUN } \\
(9,30 \%)\end{array}$ & $\begin{array}{l}\text { TURUN } \\
(4,16 \%)\end{array}$ \\
\hline Indomilk Instant $400 \mathrm{Gr}$ & $\begin{array}{c}\text { NAIK } \\
(15,8 \%)\end{array}$ & $\begin{array}{l}\text { TURUN } \\
(9,38 \%)\end{array}$ & $\begin{array}{c}\text { NAIK } \\
(15,75 \%)\end{array}$ & $\begin{array}{l}\text { TURUN } \\
(9,38 \%)\end{array}$ & $\begin{array}{c}\text { NAIK } \\
(7,10 \%)\end{array}$ \\
\hline
\end{tabular}

Sumber : Data Olahan

Perubahan laba Kotor untuk 10 produk Indofood pada tahun 2014 yang dibandingkan dengan tahun 2013 yang keseluruhunnya mengalami kenaikan harga jual dan harga pokok sedangkan untuk kuantitas penjualan dan kuantitas harga pokok mengalami fluktuasi kenaikan dan penurunan yang berbeda-beda, sehingga perubahan yang terjadi pada laba kotor pun berbeda-beda. Persentase kenaikan dan penurunan dari masing-masing produk dapat dilihat pada tabel 10 . 
Tabel 11

Persentase Perubahan Laba Kotor Tahun 2015

\begin{tabular}{|c|c|c|c|c|c|}
\hline \multirow[b]{2}{*}{ Nama Barang } & \multicolumn{5}{|c|}{2015 (Dibandingkan dengan tahun 2014) } \\
\hline & $\begin{array}{l}\text { HARGA } \\
\text { JUAL }\end{array}$ & $\begin{array}{l}\text { KUANTITAS } \\
\text { PENJUALAN }\end{array}$ & $\begin{array}{l}\text { HARGA } \\
\text { POKOK }\end{array}$ & $\begin{array}{c}\text { KUANTITAS } \\
\text { HARGA POKOK }\end{array}$ & $\begin{array}{c}\text { LABA } \\
\text { KOTOR }\end{array}$ \\
\hline Sun BC Beras Merah 8x20gr & $\begin{array}{l}\text { NAIK } \\
(4,35 \%)\end{array}$ & $\begin{array}{c}\text { NAIK } \\
(1,97 \%)\end{array}$ & $\begin{array}{l}\text { NAIK } \\
4,90 \%)\end{array}$ & $\begin{array}{c}\text { NAIK } \\
(1,97 \%)\end{array}$ & $\begin{array}{l}\text { NAIK } \\
(0,02 \%)\end{array}$ \\
\hline Indomilk Full Cream 800Gr & $\begin{array}{l}\text { NAIK } \\
(4,78 \%)\end{array}$ & $\begin{array}{l}\text { TURUN } \\
(27,62 \%)\end{array}$ & $\begin{array}{l}\text { NAIK } \\
(5,44 \%)\end{array}$ & $\begin{array}{l}\text { TURUN } \\
(27,62 \%)\end{array}$ & $\begin{array}{l}\text { TURUN } \\
(27,35 \%)\end{array}$ \\
\hline Bimoli Clasic 5 Ltr & $\begin{array}{c}\text { NAIK } \\
(8,22 \%)\end{array}$ & $\begin{array}{c}\text { NAIK } \\
(6,15 \%)\end{array}$ & $\begin{array}{c}\text { NAIK } \\
(6,82 \%)\end{array}$ & $\begin{array}{c}\text { NAIK } \\
(6,15 \%)\end{array}$ & $\begin{array}{c}\text { NAIK } \\
(25,03 \%)\end{array}$ \\
\hline La Fonte Spaghetti $500 \mathrm{Gr}$ & $\begin{array}{l}\text { NAIK } \\
(4,19 \%)\end{array}$ & $\begin{array}{l}\text { TURUN } \\
(12,12 \%)\end{array}$ & $\begin{array}{l}\text { NAIK } \\
(3,19 \%)\end{array}$ & $\begin{array}{l}\text { TURUN } \\
(12,12 \%)\end{array}$ & $\begin{array}{l}\text { TURUN } \\
(2,25 \%)\end{array}$ \\
\hline Chitato Beef Barbeque $68 \mathrm{Gr}$ & $\begin{array}{l}\text { NAIK } \\
(9,40 \%)\end{array}$ & $\begin{array}{l}\text { TURUN } \\
(5,97 \%)\end{array}$ & $\begin{array}{l}\text { NAIK } \\
(9,40 \%)\end{array}$ & $\begin{array}{l}\text { TURUN } \\
(5,97 \%)\end{array}$ & $\begin{array}{l}\text { NAIK } \\
(2,81 \%)\end{array}$ \\
\hline Promina Biscuit Susu $130 \mathrm{Gr}$ & $\begin{array}{c}\text { NAIK } \\
(4,07 \%)\end{array}$ & $\begin{array}{c}\text { NAIK } \\
(11,76 \%)\end{array}$ & $\begin{array}{c}\text { NAIK } \\
(4,34 \%)\end{array}$ & $\begin{array}{c}\text { NAIK } \\
(11,76 \%)\end{array}$ & $\begin{array}{c}\text { NAIK } \\
(12,87 \%)\end{array}$ \\
\hline Qtela Original $185 \mathrm{Gr}$ & $\begin{array}{c}\text { NAIK } \\
(7,14 \%)\end{array}$ & $\begin{array}{l}\text { TURUN } \\
(3,73 \%)\end{array}$ & $\begin{array}{c}\text { NAIK } \\
(6,96 \%)\end{array}$ & $\begin{array}{l}\text { TURUN } \\
(3,73 \%)\end{array}$ & $\begin{array}{c}\text { NAIK } \\
(4,55 \%)\end{array}$ \\
\hline $\begin{array}{l}\text { Happy Salad Pure Soya Oil } \\
\text { 5L }\end{array}$ & $\begin{array}{c}\text { NAIK } \\
(4,75 \%)\end{array}$ & $\begin{array}{l}\text { TURUN } \\
(15 \%)\end{array}$ & $\begin{array}{c}\text { NAIK } \\
(4,88 \%)\end{array}$ & $\begin{array}{l}\text { TURUN } \\
(15 \%)\end{array}$ & $\begin{array}{r}\text { TURUN } \\
(12,65 \%)\end{array}$ \\
\hline $\begin{array}{l}\text { Bu Krim Oxy Klin Higienis } \\
\text { 750Gr }\end{array}$ & $\begin{array}{c}\text { NAIK } \\
(7,84 \%)\end{array}$ & $\begin{array}{l}\text { TURUN } \\
(2,56 \%)\end{array}$ & $\begin{array}{c}\text { NAIK } \\
(9,56 \%)\end{array}$ & $\begin{array}{l}\text { TURUN } \\
(2,56 \%)\end{array}$ & $\begin{array}{l}\text { TURUN } \\
(7,51 \%)\end{array}$ \\
\hline Indomilk Instant $400 \mathrm{Gr}$ & $\begin{array}{c}\text { NAIK } \\
(3,59 \%)\end{array}$ & $\begin{array}{c}\text { NAIK } \\
(58,62 \%)\end{array}$ & $\begin{array}{c}\text { NAIK } \\
(3,89 \%)\end{array}$ & $\begin{array}{c}\text { NAIK } \\
(58,62 \%) \\
\end{array}$ & $\begin{array}{c}\text { NAIK } \\
(43,98 \%)\end{array}$ \\
\hline
\end{tabular}

Sumber : Data Olahan

Perubahan laba Kotor untuk 10 produk Indofood pada tahun 2015 yang dibandingkan dengan tahun 2014 yang keseluruhunnya mengalami kenaikan harga jual dan harga pokok sedangkan untuk kuantitas penjualan dan kuantitas harga pokok mengalami fluktuasi kenaikan dan penurunan yang berbeda-beda, sehingga perubahan yang terjadi pada laba kotor pun berbeda-beda. Persentase kenaikan dan penurunan dari masing-masing produk dapat dilihat pada tabel 11 .

Tabel 12

Persentase Perubahan Laba Kotor Tahun 2016

\begin{tabular}{|l|c|c|c|c|c|}
\hline \multirow{3}{*}{ Nama Barang } & \multicolumn{5}{|c|}{ 2016 (Dibandingkan dengan tahun 2015) } \\
\cline { 2 - 6 } & $\begin{array}{c}\text { HARGA } \\
\text { JUAL }\end{array}$ & $\begin{array}{c}\text { KUANTITAS } \\
\text { PENJUALAN }\end{array}$ & $\begin{array}{c}\text { HARGA } \\
\text { POKOK }\end{array}$ & $\begin{array}{c}\text { KUANTITAS } \\
\text { HARGA POKOK }\end{array}$ & $\begin{array}{c}\text { LABA } \\
\text { KOTOR }\end{array}$ \\
\hline & NAIK & TURUN & NAIK & TURUN & NAIK \\
Sun BC Beras Merah 8x20gr & $(16,67 \%)$ & $(3,23 \%)$ & $(16,82 \%)$ & $(3,23 \%)$ & $(11,66 \%)$ \\
\hline & NAIK & NAIK & NAIK & NAIK & NAIK \\
Indomilk Full Cream 800Gr & $(1,92 \%)$ & $(9,21 \%)$ & $(1,94 \%)$ & $(9,21 \%)$ & $(11,17 \%)$ \\
\hline & TURUN & NAIK & TURUN & NAIK & TURUN \\
Bimoli Clasic 5 Ltr & $(5,91 \%)$ & $(15,94 \%)$ & $(4,45 \%)$ & $(15,94 \%)$ & $(1,51 \%)$ \\
\hline & NAIK & TURUN & NAIK & TURUN & TURUN \\
La Fonte Spaghetti 500 Gr & $(11,86 \%)$ & $(16,09 \%)$ & $(11,25 \%)$ & $(16,09 \%)$ & $(2,77 \%)$ \\
\hline & NAIK & TURUN & NAIK & TURUN & TURUN \\
Chitato Beef Barbeque 68Gr & $(5,52 \%)$ & $(22,22 \%)$ & $(6,93 \%)$ & $(22,22 \%)$ & $(25,58 \%)$ \\
\hline & NAIK & TURUN & NAIK & TURUN & TURUN \\
Promina Biscuit Susu 130 Gr & $(4,09 \%)$ & $(1,64 \%)$ & $(4,77 \%)$ & $(1,64 \%)$ & $(3,35 \%)$ \\
\hline & NAIK & NAIK & NAIK & NAIK & NAIK \\
Qtela Original 185 Gr & $(4,61 \%)$ & $(1,55 \%)$ & $(6,14 \%)$ & $(1,55 \%)$ & $(6,30 \%)$ \\
\hline
\end{tabular}




\begin{tabular}{|l|c|c|c|c|c|}
$\begin{array}{l}\text { Happy Salad Pure Soya Oil } \\
\text { 5L }\end{array}$ & $\begin{array}{c}\text { NAIK } \\
(1,97 \%)\end{array}$ & $\begin{array}{c}\text { TURUN } \\
(11,76 \%)\end{array}$ & $\begin{array}{c}\text { NAIK } \\
(2,26 \%)\end{array}$ & $\begin{array}{c}\text { TURUN } \\
(11,76 \%)\end{array}$ & $\begin{array}{c}\text { TURUN } \\
(13,93 \%)\end{array}$ \\
\hline $\begin{array}{l}\text { Bu Krim Oxy Klin Higienis } \\
750 \mathrm{Gr}\end{array}$ & NAIK & TURUN & NAIK & TURUN & TURUN \\
$(6,67 \%)$ & $(7,89 \%)$ & $(7,44 \%)$ & $(7,89 \%)$ & $(7,95 \%)$ \\
\hline Indomilk Instant 400 Gr & NAIK & NAIK & NAIK & NAIK & NAIK \\
$(11,37 \%)$ & $(23,91 \%)$ & $(11,29 \%)$ & $(23,91 \%)$ & $(42,82 \%)$ \\
\hline
\end{tabular}

Sumber : Data Olahan

Perubahan laba Kotor untuk 10 produk Indofood pada tahun 2016 yang dibandingkan dengan tahun 2015, produk Bimoli Clasic 5L mengalami penurunan harga jual dan harga pokok, lalu untuk 9 produk lainnya mengalami kenaikan harga jual dan harga pokok sedangkan untuk kuantitas penjualan dan kuantitas harga pokok mengalami fluktuasi kenaikan dan penurunan yang berbeda-beda, sehingga perubahan yang terjadi pada laba kotor pun berbeda-beda. Persentase kenaikan dan penurunan dari masing-masing produk dapat dilihat pada tabel 12 .

Tabel 13

Persentase Perubahan Laba Kotor Tahun 2017

\begin{tabular}{|c|c|c|c|c|c|}
\hline \multirow[b]{2}{*}{ Nama Barang } & \multicolumn{5}{|c|}{2017 (Dibandingkan dengan tahun 2016) } \\
\hline & $\begin{array}{l}\text { HARGA } \\
\text { JUAL }\end{array}$ & $\begin{array}{l}\text { KUANTITAS } \\
\text { PENJUALAN }\end{array}$ & $\begin{array}{l}\text { HARGA } \\
\text { POKOK }\end{array}$ & $\begin{array}{c}\text { KUANTITAS } \\
\text { HARGA POKOK }\end{array}$ & $\begin{array}{c}\text { LABA } \\
\text { KOTOR }\end{array}$ \\
\hline Sun BC Beras Merah 8x20gr & $\begin{array}{c}\text { NAIK } \\
(12,14 \%)\end{array}$ & $\begin{array}{l}\text { TURUN } \\
(0,67 \%)\end{array}$ & $\begin{array}{c}\text { NAIK } \\
(13,57 \%)\end{array}$ & $\begin{array}{l}\text { TURUN } \\
(0,67 \%)\end{array}$ & $\begin{array}{l}\text { TURUN } \\
(0,41 \%)\end{array}$ \\
\hline Indomilk Full Cream 800Gr & $\begin{array}{l}\text { NAIK } \\
(2,44 \%)\end{array}$ & $\begin{array}{c}\text { NAIK } \\
(10,84 \%)\end{array}$ & $\begin{array}{l}\text { NAIK } \\
(2,44 \%)\end{array}$ & $\begin{array}{l}\text { NAIK } \\
(10,84)\end{array}$ & $\begin{array}{c}\text { NAIK } \\
(13,56 \%)\end{array}$ \\
\hline Bimoli Clasic 5 Ltr & $\begin{array}{c}\text { NAIK } \\
(10,36 \%)\end{array}$ & $\begin{array}{l}\text { TURUN } \\
(1,25 \%)\end{array}$ & $\begin{array}{l}\text { NAIK } \\
(10,36 \%)\end{array}$ & $\begin{array}{l}\text { TURUN } \\
(1,25 \%)\end{array}$ & $\begin{array}{c}\text { NAIK } \\
(8,99 \%)\end{array}$ \\
\hline La Fonte Spaghetti $500 \mathrm{Gr}$ & $\begin{array}{c}\text { NAIK } \\
(11,36 \%)\end{array}$ & $\begin{array}{l}\text { NAIK } \\
(1,37 \%) \\
\end{array}$ & $\begin{array}{c}\text { NAIK } \\
(12,53 \%)\end{array}$ & $\begin{array}{l}\text { NAIK } \\
(1,37 \%)\end{array}$ & $\begin{array}{l}\text { NAIK } \\
(5,54 \%)\end{array}$ \\
\hline Chitato Beef Barbeque $68 \mathrm{Gr}$ & $\begin{array}{c}\text { NAIK } \\
(11,80 \%)\end{array}$ & $\begin{array}{l}\text { NAIK } \\
(6,12 \%)\end{array}$ & $\begin{array}{l}\text { NAIK } \\
(9,01 \%)\end{array}$ & $\begin{array}{l}\text { NAIK } \\
(6,12 \%)\end{array}$ & $\begin{array}{c}\text { NAIK } \\
(29,31 \%)\end{array}$ \\
\hline Promina Biscuit Susu 130 Gr & $\begin{array}{l}\text { NAIK } \\
(7,42 \%)\end{array}$ & $\begin{array}{c}\text { NAIK } \\
(1,67 \%)\end{array}$ & $\begin{array}{c}\text { NAIK } \\
(8,20 \%)\end{array}$ & $\begin{array}{c}\text { NAIK } \\
(1,67 \%)\end{array}$ & $\begin{array}{c}\text { NAIK } \\
(1,94 \%)\end{array}$ \\
\hline Qtela Original $185 \mathrm{Gr}$ & $\begin{array}{c}\text { NAIK } \\
(4,41 \%)\end{array}$ & $\begin{array}{l}\text { TURUN } \\
(3,05 \%)\end{array}$ & $\begin{array}{l}\text { NAIK } \\
(4,95 \%)\end{array}$ & $\begin{array}{l}\text { TURUN } \\
(3,05 \%)\end{array}$ & $\begin{array}{l}\text { TURUN } \\
(3,64 \%)\end{array}$ \\
\hline $\begin{array}{l}\text { Happy Salad Pure Soya Oil } \\
5 \mathrm{~L}\end{array}$ & $\begin{array}{c}\text { NAIK } \\
(2,29 \%)\end{array}$ & $\begin{array}{c}\text { NAIK } \\
(53,33 \%)\end{array}$ & $\begin{array}{c}\text { NAIK } \\
(2,43 \%)\end{array}$ & $\begin{array}{l}\text { NAIK } \\
(53,33 \%)\end{array}$ & $\begin{array}{c}\text { NAIK } \\
(53,40 \%)\end{array}$ \\
\hline $\begin{array}{l}\text { Bu Krim Oxy Klin Higienis } \\
\text { 750Gr }\end{array}$ & $\begin{array}{c}\text { NAIK } \\
(5,97 \%)\end{array}$ & $\begin{array}{l}\text { NAIK } \\
(2,86 \%)\end{array}$ & $\begin{array}{c}\text { NAIK } \\
(6,63 \%)\end{array}$ & $\begin{array}{l}\text { NAIK } \\
(2,86 \%)\end{array}$ & $\begin{array}{c}\text { NAIK } \\
(2,61 \%) \\
\end{array}$ \\
\hline Indomilk Instant $400 \mathrm{Gr}$ & $\begin{array}{c}\text { NAIK } \\
(3,09 \%)\end{array}$ & $\begin{array}{l}\text { TURUN } \\
(1,75 \%)\end{array}$ & $\begin{array}{c}\text { NAIK } \\
(5,62 \%)\end{array}$ & $\begin{array}{l}\text { TURUN } \\
(1,75 \%)\end{array}$ & $\begin{array}{l}\text { TURUN } \\
(21,98 \%)\end{array}$ \\
\hline
\end{tabular}

Sumber : Data Olahan

Perubahan laba Kotor untuk 10 produk Indofood pada tahun 2017 yang dibandingkan dengan tahun 2016 yang keseluruhunnya mengalami kenaikan harga jual dan harga pokok sedangkan untuk kuantitas penjualan dan kuantitas harga pokok mengalami fluktuasi kenaikan dan penurunan yang berbeda-beda, sehingga perubahan yang terjadi pada laba kotor pun berbeda-beda. Persentase kenaikan dan penurunan dari masing-masing produk dapat dilihat pada tabel 13 .

Berdasarkan hasil penelitian, penyebab turunnya laba kotor pada perusahaan terjadi karena beberapa faktor, yaitu : 
1. Terjadi kenaikan harga pada harga pokok atau harga beli suatu barang yang mengakibatkan naiknya harga jual, yang memungkinkan akan mengakibatkan penurunan pada volume penjualan karena harga jual yang tidak dapat bersaing dipasaran.

2. Bertambahnya biaya-biaya operasional perusahaan, seperti ongkos pengiriman. Hal tersebut dapat memicu kenaikan dari harga jual produk itu sendiri.

3. Terdapat beberapa produk yang kurang diminati oleh konsumen, yang nantinya akan mengakibatkan terjadinya pemotongan harga jual, sehingga akan berdampak pada kenaikan laba kotor.

Kenaikan atau penurunan harga jual produk salah satunya dipengaruhi oleh harga pokok, sementara kanaikan dan penurunan dari harga pokok itu sendiri dipicu oleh kuanitas atau jumlah penjualan produk. Setelah penelitian dilakukan dan diketahui penyebabnya, perusahaan sebaiknya mempertimbangkan beberapa hal dalam menentukan harga jual :

1. Harga beli barang/produk

2. Agen/distributor

3. Biaya

4. Harga pasar

5. Kebutuhan dan minat konsumen

Berdasarkan uraian tersebut di atas, maka dapat disimpulkan bahwa, analisis laba kotor dapat dijadikan sebagai salah satu alat dalam menentukan naik turunnya harga jual. Dimana setelah dianalisis selisih laba kotornya, maka ditemukan selisih-selisih yang tidak menguntungkan yang menyebabkan laba kotor menurun dari tahun sebelumnya. Terutama selisih yang diakibatkan oleh harga jual. Kemudian selisih-selisih tersebut dianalisis lebih lanjut dan dicari penyebab penyimpangannya. Kemudian perusahaan dapat mengambil tindakan atas penyimpangan untuk dicari pemecahannya sehingga dapat meminimalkan penyimpangan yang terjadi, yaitu dengan melakukan analisis lebih lanjut terhadap bagian atau biaya apa yang menyebabkan terjadinya selisih, dan siapa pihak yang bertanggung jawab terhadap penyimpangan tersebut sehingga dapat dilakukan perbaikan dimasa mendatang.

Dalam upaya meningkatkan laba kotor perusahaan, maka perusahaan perlu memilih dengan cermat agen atau distributor penyedia barang, karena tinggi rendahnya harga beli juga mempengaruhi pada tinggi rendahnya harga jual. Selain itu juga perusahaan juga harus memperhitungkan harga pasar, biaya-biaya yang dikeluarkan, serta kebutuhan dan minat konsumen agar perusahaan dapat bersaing dengan perusahaan lain yang sejenis. Dengan menentukan naik turunnya harga jual yang tepat dan juga promosi yang baik, maka penjualan akan meningkat, sehingga laba yang diharapkan pun dapat meningkat.

\section{F. Kesimpulan}

Berdasarkan hasil analisis yang telah dilakukan, maka dapat disimpulkan bahwa :

1. Harga jual dan harga pokok Sun BC Beras Merah 8x20 Gr, Indomilk Full Cream 800 Gr, La Fonte Sphagetti 500 Gr, Chitato Beef Barbeque 68 Gr, Promina Biscuit Susu 130 Gr, Qtela Original 185 Gr, Happy Salad Pure Soya Oil 5 Ltr, Bu Krim Oxy Clean Higienis $750 \mathrm{Gr}$ dan Indomilk Instant $400 \mathrm{Gr}$ mengalami kenaikan harga jual dari tahun 2014 hingga 2017. Sedangkan untuk produk Bimoli Clasic 5 Ltr mengalami penurunan harga jual pada tahun 2016 dan kenaikan harga jual di tahun 2014, 2015, dan 2017. 
2. Kuantitas penjualan dan kuantitas harga pokok dari Sun BC Beras Merah 8x20 Gr, Indomilk Full Cream 800 Gr, Bimoli Clasic 5 Ltr La Fonte Sphagetti 500 Gr, Chitato Beef Barbeque 68 Gr, Promina Biscuit Susu 130 Gr, Qtela Original 185 Gr, Happy Salad Pure Soya Oil 5 Ltr, Bu Krim Oxy Clean Higienis 750 Gr dan Indomilk Instant 400 Gr mengalami perubahan secara fleksibel dari tahun 2014 - 2017. Perubahan kuantitas penjualan disebabkan oleh minat konsumen dan harga jual itu sendiri. 


\section{DAFTAR PUSTAKA}

Arikunto, Surhasini. 2002. Prosedur Penelitian Suatu Pendekatan Praktik.Jakarta: Rineka Cipta.

Baridwan, Zaki, 2013. Sistem Informasi Akuntansi. Yogyakarta: BPFE

Harahap, Sofyan Syafri. 2008. Analisis Kritis Laporan Keuangan. Jakarta: RajaGrafindo Persada.

Hery, 2017. Teori Akuntansi (Pendekatan Konsep dan Analisis). Jakarta: Grasindo.

Kasmir, 2016. Analisis Laporan Keuangan. Jakarta: RajaGrafindo Persada.

Rahardjo, Budi, 2009. Laporan Keuangan Perusahaan. Yogyakarta: Gadjah Mada University Press.

Santoso, Iman, 2009. Akuntansi Keuangan Menengah (Buku Dua). Bandung: Refika Aditama.

Santoso, Iman, 2010. Akuntansi Keuangan Menengah (Buku Satu). Bandung: Refika Aditama.

Sodikin, Slamet Sugiri, Bogat Agus Riyono, Akuntansi Pengantar 1. Yogyakarta: Sekolah Tinggi Ilmu Manajemen YKPN.

Soehartono, Irawan. 2004. Metode Penelitian Sosial. Bandung: PT.Remaja rosdakarya.

Sunyoto, Danang, 2016. Metodologi Penelitian Akuntansi. Bandung: Refika Aditama.

Indriani Masaluni. 2016. Analisis Perhitungan Pendapatan Bunga pada Koperasi Simpan Pinjam Warga Makmur Kabupaten Gorontalo. Skripsi tidak dipublikasikan. Universitas Gorontalo.

Livia Chandra. 2012. Pengaruh Penjualan Bersih terhadap Laba Kotor Suatu Perusahaan. Skripsi tidak dipublikasikan. Universitas Atma Jaya Makassar.

Magun Istonapi. 2012. Analisis Perubahan Laba Kotor pada PT Kaltim Parna Industri Di Bontang. Skripsi tidak dipublikasikan. Universitas Mulawarman.

Marina Tjani Ontalu. 2015. Pengaruh Penjualan Angsuran terhadap Pendapatan pada PT. Suzuki Sinar Galesong Mandiri Kota Gorontalo. Skripsi tidak dipublikasikan. Universitas Gorontalo.

Medi Tri Purwanto. 2013. Analisis Laba Kotor sebagai Salah Satu Alat dalam Menetapkan Harga Jual pada Perusahaan Telur Asin Eni Jayabrebes. Skripsi tidak dipublikasikan. STIE Widya Manggalia Brebes.

Risma Catharina Rahmawaty Sirait. 2007. Analisis Perhitungan Harga Pokok Produksi dan Penentuan Harga Jual Produk Coca Cola pada PT. Coca Cola Bottling Indonesia Unit Medan. Skripsi tidak dipublikasikan. Universitas Sumatera Utara. 
Herman, 2006. Penentuan Harga Jual. https://www.kompasiana.com/lasmida raseila/penentuan-harga-jual_563flc86f77e612609970b17. (diakses 3 Januari 2018)

Machfoedz. Pengertian Harga dan Tujuannya menurut Para Ahli, 2015. http://www.informasi-pendidikan.com/2015/12/pengertian-harga-dan-tujuannyamenurut.html. (diakses 1 Desember 2017).

Martani. Pengertian Akuntansi Keuangan: Fungsi \& Standar Akuntansi Keuangan, 2016. http://www.contohsurat.co.id/2016/09/akuntansi-keuangan.html. (di akses 1 Desember 2017).

Munirah, dkk. 2014. Memahami Konsep Analisis Laba Kotor. (Online). (https://www.academia.edu/10917018/ANALISIS_LABA_KOTOR, diakses 1 Desember 2017).

Nursalam. Pengertian Teknik Purposive Sampling menurut Para Ahli. http://www.pengertianmenurutparaahli.net/pengertian-teknik-purposive-samplingmenurut-para-ahli/. (diakses 1 Desember 2017)

Sugiarto. Pengertian Akuntansi Keuangan beserta Fungsi dan Standarisasi nya, 2016. http://rocketmanajemen.com/pengertian-akuntansi-keuangan/. (di akses 1 Desember 2017)

Warren Reev Fess. Pengertian Akuntansi Keuangan: Fungsi \& Standar Akuntansi Keuangan, 2016. http://www.contohsurat.co.id/2016/09/akuntansi-keuangan.html. (di akses 1 Desember 2017).

Widisudharta. Metodelogi Penelitian. https://widisudharta.weebly.com/metode-penelitianskripsi.html. (diakses 1 Desember 2017) 